\title{
Setting course for demand response in the service sector
}

\author{
Katharina Wohlfarth (D) Marian Klobasa • \\ Anke Eßer
}

Published online: 31 August 2018

C) The Author(s) 2018

\begin{abstract}
The increasing share of renewable energies in electricity generation is within the scope of the energy transition and will lead to a more volatile generation of electricity. A more flexible energy demand could contribute to handling the resulting challenges in electricity grid management. The service sector is one of the target groups for utilizing flexible demand, also called demand response (DR). Supermarkets, hotels, and office buildings can be found in regions throughout Germany. This could be an advantage regarding the compensation of grid instability in any region, compared to more locally focused industrial enterprises. First estimations point out considerable unused DR potentials for the service sector. However, currently, there is less knowledge about flexibility options in the service sector than in industry. Moreover, market barriers, such as a missing adequate regulatory framework offering
\end{abstract}

K. Wohlfarth $(\bowtie) \cdot$ M. Klobasa $\cdot$ A. Eßer

Fraunhofer Institute for Systems and Innovation Research ISI, Breslauer Straße 48, 76139 Karlsruhe, Germany

e-mail: katharina.wohlfarth@isi.fraunhofer.de

M. Klobasa

e-mail: marian.klobasa@isi.fraunhofer.de

A. Eßer

e-mail: anke.esser@isi.fraunhofer.de

K. Wohlfarth

Copernicus Institute of Sustainable Development, Utrecht University, Princetonlaan 8a, 3584 CB Utrecht, Netherlands attractive incentives prevent that the potentials are tapped. Therefore, in this paper, we first analyze survey data from 1.000 enterprises of the service sector in Germany to identify subsectors that have a high share of flexible cross-sectoral technologies in electricity consumption. Data indicates that the subsectors trade, restaurants, and hotels as well as office-like buildings are the most promising subsectors of the service sector regarding demand response potential, since they have a high stock in flexible cooling appliances, air conditioning, and ventilation. In a second step, we conducted stakeholder interviews, to find specific barriers, drivers, and possible starting points in each of the identified subsectors. Still unapt or missing regulatory framework conditions, low profitability, and a lack of knowledge regarding flexibility potentials and marketing mechanisms seem to be the main barriers. However, framework conditions promoting demand response measures are improving, e.g., technical standards and latest regulatory revisions. This indicates that in order to tap the existing demand response potentials in the service sector, the value of flexibility in demand needs to be appreciated, e.g., by facilitating market participation or by creating offers resp. rewarding the enterprises' flexibility of demand. In addition, addressing demand response issues in already existing policy measures, such as energy audits could raise awareness and knowledge.

Keywords Demand response $\cdot$ Demand side management $\cdot$ Service sector Tertiary sector Flexible technologies $\cdot$ Regulations 


\section{Introduction}

The German electric energy system is currently undergoing a major transformation and will most likely continue to do so until 2050. By 2050, the contribution of renewable energy sources shall have a share of $80 \%$ in the electric energy mix (Deutscher Bundestag 2010). Among the largest contributors will be wind and solar power. Due to the high dependency on weather conditions, electricity generation from those sources is volatile and hard to predict. As a consequence, major challenges for the German electricity grid regarding system stability and security of supply will arise.

System operators dispose of multiple measures to address the issues caused by volatile energy resources. The currently most common measures are redispatching conventional power plants or to use balancing energy to offset the volatile generation from renewable energy sources. This does, however, result in higher costs for the operators of those power plants (Dena 2010).

As the final goals are maintaining security of supply and at the same time having a highly efficient energy system, other options might become increasingly important in the future. One of those options is to adjust demand to the volatile electricity generation. This concept is usually called "demand-side management" (DSM). However, the term DSM is not always used consistently. Some concepts treat demand response or loadshift as synonymous. Other definitions use DSM measures as a hypernym for related concepts, subsuming changes in the amount of energy use as well as changes in the time-of-use, and thereby summarize approaches to operate energy demand (Cowart et al. 2003; Palensky and Dietrich 2011; IEA 2016). Following the latter, we refer to DSM as changes of the demand side of markets. The aim is to achieve a more efficient energy system (e.g., an overall lower need of electric energy production and thus also less adjustment by conventional power plants). We use the term demand response (DR) as one mechanism with which a single consumer can contribute to DSM by changing his consumption pattern "behind the meter." It comprises changes in his consumption behavior as well as the different use of technologies, i.e., the adjustment or shifting of loads of flexible electric applications at certain points of time. This means, DR is included in the term DSM and deals mostly with shortterm adjustments in consumption.

The overall aim in DR or DSM for the energy system is to eventually avoid conventional balancing power plants and to support grid stability. The future substitution of conventional balancing power plants by DR balancing options is attractive in several ways: avoiding power plants for balancing power additionally contributes to decreasing $\mathrm{CO}_{2}$ emissions by substituting fossil fuels (Dena 2010). Moreover, DR could be a more cost-efficient option to deal with the intermittency of renewable energies than storage options or reinforcing the grid infrastructure.

In order to evaluate the consumers' DR potential, four different types of potentials should be distinguished (Rudolph and Wagner 1997; von Roon and Gobmaier 2010) - the theoretical, the technical, the economic, and the practical potential. The theoretical potential describes the summed load of all applications with eligible technologies for DR, and therefore gives an upper limit for the DR potential. The technical potential considers additionally technical and operational restrictions reducing the available DR potential of the applications, which includes, among others, load profiles, ramp up/down times, partial load restrictions, or security regulations. In contrast to the technical potential, the economic potential takes the economic viability of the DR options for the applications into account, considering investments, operational expenses, and possible financial profits. The practical potential is highly dependent on subjective opinions and barriers like perceptive restrictions, knowledge, and complexity of decisionmaking, and therefore is also difficult to quantify in terms of the actual load available for DR compared to the other mentioned potentials.

\section{Literature overview and research questions}

In Europe, mainly the industrial sector has been in the scope of research on DR. Gils (2014) found in his research an average theoretical potential of $93 \mathrm{GW}$ for load reduction across all sectors (industrial, tertiary, private) in Europe with main contributors being energy intensive industries. In the case of Germany, existing studies attribute a substantial technical potential to the energy intensive sector (see Table 1), mainly due to the energy intensity of the sector-specific processes (VDE 2012; Klobasa et al. 2013). The main advantage of industrial DR processes is the ease of system integration and accessibility due to a high and easy to predict load demand of the individual processes (VDE 2012). Yet, a large share of the industrial potential lies in within the production processes of the enterprises, which can be problematic to be modified (Dena 2010; VDE 2012; Focken et al. 2011; Klobasa et al. 2013). Especially the fear of loss in product quality, disruption of continuous production processes, and resulting financial 
losses are perceived as barriers (Olsthoorn et al. 2015). However, other studies additionally estimate that industrial cross-sectional technologies, such as compressed air, ventilation, pumps, and cooling, have a high economic DR potential (2.4 GW of $3.5 \mathrm{GW}$ total economic potential; Dena 2010). This increases the need of a potential exploitation of DR in other sectors.

Since the tertiary/ service sector contributes to $29 \%$ to the overall electricity consumption in Germany (2013), it can possibly take an important role for DR (AGEB 2015). There are already some studies which identify viable technologies (Stadler 2005; Gils 2014) and estimate theoretical, technical, and economic potentials via modeling (Klobasa 2007; VDE 2012; Dena 2010). Those studies give an idea of the extent of the DR potential in the service sector (see Table 1). In particular, Dena (2010) shows that the tertiary sector can contribute a significant amount towards the future DR potential if the right economic incentives are set (Dena 2010).

According to Stadler (2005), Klobasa (2007), or Grein and Pehnt (2011), the most promising and easy accessible technological appliance in the service sector is cold storage in the food-trading sector. Research has been done to address system integration and marketability (e.g., Grein et al. 2009; Focken et al. 2011). Other research focused on potential barriers and enablers influencing the integration of DR into the energy system. A British study highlights the large expected potentials in the non-domestic sector (Element Energy Limited 2012) and found that the fear of negative impacts on service levels and missing financial incentives are two of the main barriers. These are comparable barriers as in industry, but compared to the industrial sector, there is probably greater lack of awareness of potentials and options. Additionally, arrangements for
DR are complex and offers to access the market are missing. In Germany, many of the barriers to DR are on the regulatory side (Jahn and Gottstein, 2013). Regarding enablers Goldman et al. (2007) and Finn and Fitzpatrick (2014) analyzed alternative electricity tariff models (e.g., time-of-use, critical peak pricing). In addition, education, information, and case studies are perceived as propelling measures to promote DR (Element Energy Limited 2012).

The USA is often seen as exemplary for the use of DR, because of their years of experience in implementations (cp. California Public Utilities Commission 2017). California is a leader in automating DR, especially in reducing peak demand. Kiliccote et al. (2010) provide a summary of participation and DR strategies for commercial buildings to reduce peak demand (mainly retail stores). Peak reductions between 5 and $15 \%$ are reported with an average of $13 \%$. The Western University of Ontario, Canada, achieves $20 \%$ of load shaving during the summer peaks, which achieved 2 million dollar savings over a 2-year period, i.e., getting more back than invested in. The campus community is involved in taking actions, and the energy use of any building across campus can be monitored. In early 2015, the Western University received the Environmental Award of Excellence from the Minister of Environment and Climate Change (Western University 2017).

The California Public Utilities Commission informs on its webpage about DR programs and research findings. Pacific Gas \& Electric (PG\&E), southern California Edison (SCE), and San Diego Gas and Electric Company (SDG\&E) each publish monthly reports on their DR actions and provide detailed information on their programs and how to participate. Case studies highlighting companies that have saved on energy and

Table 1 Estimated demand response potentials by different studies

\begin{tabular}{|c|c|c|c|c|c|c|}
\hline \multirow[t]{2}{*}{ Study } & \multicolumn{2}{|c|}{ Estimated maximum potential } & \multirow[t]{2}{*}{ Potential type } & \multirow[t]{2}{*}{ Proj. years/base } & \multirow[t]{2}{*}{ Notes } & \multirow[t]{2}{*}{ Sector } \\
\hline & $\begin{array}{l}\text { Peak power } \\
(\mathrm{GW})\end{array}$ & $\begin{array}{l}\text { Flexible energy } \\
\text { (TWh) }\end{array}$ & & & & \\
\hline VDE 2012 & 4.5 & & Technical & $2010-2030$ & Energy intensive industries & Industry \\
\hline Dena 2010 & 3.5 & 12.2 & Economic & 2020 & $\begin{array}{l}\text { Energy intensive industries } \\
\text { and cross-sectional technologies }\end{array}$ & Industry \\
\hline Klobasa 2007 & 10.3 & 6.3 & Theoretical & 2004 & Cross-sectional technologies & Service \\
\hline VDE 2012 & $1.4-1.8$ & $5-9.7$ & Technical & $2010-2030$ & $\begin{array}{l}\text { Based on standard load profiles } \\
\text { and 500,000 inhabitant model city }\end{array}$ & Service \\
\hline Dena 2010 & 1.6 & 5.7 & Economic & 2020 & Roll-out with financial incentives & Service \\
\hline
\end{tabular}


costs utilizing automated DR (auto-DR) are documented, too.

Bayer (2014) argues that studies on DR from the USA cannot be seen as exemplary or transferrable for Germany in general. The potential of the sectors of shiftable resp. sheddable loads is overestimated due to different definitions of terms and not least because the use of emergency generators and efficiency measures are included. Additionally, the switching of loads is only meant as emergency procedure, not as regular loadshift to adjust to the generation of wind and PV electricity. Thus, no recommendations for the German operating reserve market can be given due to the different purposes of the markets and regulations. Anyway, case studies and their lessons learned can indicate the functioning of technical requirements and deliver experiences with organizational constraints.

But even though studies on DR in the service sector do exist, practical and specific knowledge about DR integration of processes used in the service sector remains scarce. Unlike the industrial sector, the trade and service sector has been less explored regarding DR potential, and there is less practical experience in conducting DR measures. Specific conditions and resulting barriers, as well as viable starting points for German companies of this sector are mostly unknown. The main issues in this sector are the lack of extensive comparable data to evaluate DR and the heterogeneity of the operational fields. However, currently, it is still not clear how to design these incentives to exploit the DR potential in the service sector.

Therefore, our study focuses on two main issues: first, the identification of the most promising subsectors of the service sector depending on electricity consumption and availability and the share of consumption of flexible technologies; and second, the analysis of the practicability of using the identified technologies in the selected subsectors by taking the enterprises' perspective into account. The aim is to determine specific starting points for measures and which requirements need to be given.

Our research focuses on the following questions:

- Which technologies and subsectors of the service and trade sector seem most promising for demand response?
In case of a promising sector:

- Which conditions and barriers affect the realization of the potential?

- What can be done to tap them?

The final goal of this study is to identify and characterize those promising sectors and find the needed conditions, regulatory and non-regulatory, in order to gain access to the available DR potential.

\section{Regulatory framework and market conditions for DR in Germany}

Overview of regulatory and market instruments

The DR potentials are evaluated, taking the regulatory and market conditions in Germany into account. In Germany, flexible loads can be traded on the balancing as well as on the spot market. Moreover, transmission system operator and DR providers can reach an agreement on using the loads for congestion management under the Sheddable Load Act (Abschaltbare Lasten Verordnung-AbLaV 2016). Moreover, the Electricity Access Charge Ordiance (StromNEV 2005) currently constitutes a regulatory barrier for the use of the DR potential. In the following, those marketing potentials and regulatory barriers are briefly discussed.

\section{Marketing offlexible loads on balancing and spot markets}

Power plants as well as flexible consumer loads have to prequalify in order to access the balancing markets. The prequalification guarantees that they meet the minimum technical market requirements. In Germany, the balancing market is split into three submarkets, the primary, secondary, and minutes reserve market. In the last few years, regulations have been adapted to facilitate market participation for smaller loads. Among other things, lower minimum bids and shorter bidding cycles have been introduced (cf. SEDC 2015).

In the primary reserve market (or frequency containment reserve market), power plants and consumer loads which are available within $30 \mathrm{~s}$ can participate. The minimum bid size amounts to $1 \mathrm{MW}$. In the secondary reserve market (or automated frequency restoration reserve market), loads have to be available within $5 \mathrm{~min}$. 
The minimum bid size amounts to $5 \mathrm{MW}$. To participate in the minutes reserve market (or manual frequency restoration reserve market), loads have to be available within $15 \mathrm{~min}$. The minimum bid size in this market is $5 \mathrm{MW}$ as well.

However, in the secondary, as well as in the minutes reserve market, smaller loads can be pooled, e.g., by third-party market players, such as aggregators. Currently, the main barrier to balancing market participation of DR is that there are no standardized processes and contracts for the settlements between aggregators, balancing group managers, and suppliers. Yet, the German regulatory agency Bundesnetzagentur (BNetzA) and other relevant stakeholders are currently discussing further standardization (the "aggregatormodel"), which suggests a standardized process, in particular for quantity balancing and financial compensation between aggregators and balancing group managers (cf. BNetzA 2016).

On the spot market, too, flexible consumer loads can either participate directly or via aggregators with the same contractual difficulties as for the operative reserve market (cf. SEDC 2015). Moreover, indirect participation is possible by negotiating flexible tariffs with the energy suppliers, who use the demand side flexibility within their portfolio optimization. However, profits from participation in balancing as well as spot markets are currently rather low, e.g., because of overcapacities and low prices for primary energy (Eßer et al. 2016).

\section{The Sheddable Loads Act}

The AbLaV was issued in 2012 and revised in 2016. It allows transmission system operators to advertise their needs for sheddable loads for balancing or redispatch. In total, they tender $750 \mathrm{MW}$ of immediately sheddable loads (reaction time within seconds) as well as of quickly available loads (max. 15-min reaction time). The revision in 2016 was made, because participation was rather limited in the first 4 years after implementation. To increase participation, the size of minimum bids was reduced from 50 to $5 \mathrm{MW}$ in 2016. Moreover, pooling of smaller loads and the participation of flexibility providers connected to the medium voltage grid were facilitated. Consequently, the AbLAV is now accessible for smaller loads, e.g., from the service sector.
Restrictions for the marketing of DR through the Electricity Access Charge Ordinance

According to StromNEV (2005), electricity consumers can profit from lower grid fees in case of so-called special types of grid use. This is the case if either their electricity consumption exceeds $10 \mathrm{GWh}$ within at least 7000 utilization hours (intense grid use), or if their maximum electricity purchase lies outside the highload periods defined by the network operator (atypical grid use) (StromNEV§19, sec. 1 and 2). Since DR can result in higher peak loads or considerable load reductions, the DR supplier risks losing his grid fee privileges. Since this loss would be larger than possible avails through the marketing of DR, DR is unattractive for consumers currently benefitting from $\S 19$ StromNEV.

Status quo of demand response in the service sector

In particular, large, energy-intense enterprises or thirdparty players participate in the abovementioned markets for flexible loads. In the balancing market, only 62 providers (regelleistung.net 2016) are prequalified with $2500 \mathrm{MW}$ of flexible consumer loads. Only $25 \mathrm{MW}$ of consumer loads actually participate in the secondary balancing reserve market, while $160 \mathrm{MW}$ participate in the minute reserve market. Most of the enterprises participating are from the industrial sector, e.g., aluminum or steel, operators of operating reserve pools, and virtual power plants with decentralized generating capacities for consumer loads. Companies from the service sector have not been participating in this market so far (Weißbach 2015).

This has several reasons: First, many flexible consumer loads from the service sector do not fulfill the preconditions for participation, such as minimum bid sizes. Pooling is an option, but regarding the current conditions; pooling of smaller loads is not beneficial for aggregators or DR-service providers (Eßer et al. 2016). As described in the section above, the effort resulting from the lack of standardization is too high compared to possible rewards. Thus, the balancing markets are not very attractive for flexible consumer loads from the service sector.

However, some large enterprises from this sector have recently started to participate in the spot market and have tried to minimize the energy costs using DR. Other DR options are the minimization of peak loads or 
the classification for devices with atypical grid loads, which results in lower grid fees for the customer.

Until 2016, the AbLaV only addressed larger consumer loads, which resulted in not more than seven contracts under that regulation (regelleistung.net 2017). In interviews with the representative stakeholders of subsectors, the AbLAV was therefore repeatedly called to be "a hidden subsidy of energy-intense industry," which indirectly excludes companies from other sectors from that option. Since the revision of the $\mathrm{AbLaV}$ opens the instrument for smaller sheddable loads, a participation of loads from the service sector might now be more attractive.

\section{Methodological approach}

Our methodological approach consists of two parts: the analyses of quantitative survey data and qualitative stakeholder interviews. Concerning survey data, we analyze data from a study on "Energy consumption of the tertiary sector (trade, commerce, and services) in Germany" (Schlomann et al. 2015). The study contained a survey of approximately 2000 enterprises in the tertiary sector, including the typical subgroups: trade, commerce and services plus agriculture, small manufacturing enterprises, and military. This allows for detailed analyses of the relevant subsectors. The distinction of the tertiary sector in industry (affecting esp. the distinction between manufacturing enterprises and industry) is done in analogy to the official energy balances of Germany (AGEB 2014). As the focus is on energy consumption, the subsectors were composed based on structural similarity, grouping enterprises together, which do not necessarily belong to the same NACE-codes (Statistical Classification of Economic Activities in the European Community; e.g., office-like enterprises including a large variety of objects of the enterprises on comparable structure). The survey was conducted in 2014 and contained questions about companies' characteristics and other energy-related items (for more details cp. Schlomann et al. 2015). In our analysis on the DR potential, we focus on data regarding energy consumption of subsectors, availability of technologies with flexibility potential and the energy balances for applications. The relevance of the share of one subsector compared to the whole sector and the availability and share of demand, which is caused by flexible technologies, is our decision criteria indicating promising subsectors for DR.

Having identified the most important subsectors, we contribute qualitative data of interviews with stakeholders to examine framework conditions, possible barriers and practical starting points to tap the DR potential. The decision to use qualitative data was made, because our interest lay especially in the sensitivities of each subsector and the nuts-and-bolts of feasibility. Those can hardly be expressed in numbers for loads or energy, but strongly affect the actual, practical potential, and should therefore necessarily be taken into account for practical issues.

We interviewed at least one stakeholder for each of the identified promising subsectors and representatives for more super ordinate stakeholders like aggregators, consultants, or energy service providers (Table 2).

Our interviewed stakeholders represent a larger number of enterprises for our selected subsectors. It was not our aim to ascertain a statistical relevant number of interviews, but to interview the relevant representatives for our topic. Thus, we received individual perspectives of the topic. However, those perspectives converged into a coherent overview of the situation for DR in the service sector, giving us the basis for further in-depth studies of promising subsectors for DR.

The interview guideline consisted of three main parts: an introductory part where the aim of the study was explained and the interviewee introduced himself/ herself, a second part with questions about the availability of DR options or previous related experiences, and a last part focusing on barriers and drivers influencing the chances to implement DR measures. We designed the guideline in a semi-structured way to give the interviewees the chance to add enhancing comments and issues we did possibly not anticipate while designing the survey. All calls were intended more as discussions than interrogations to gain deeper insights into points influencing the interviewee's attitude and way of decision-making. The interviews were conducted via telephone in the second half of 2016 and usually took about $1 \mathrm{~h}$. The analysis of the interview data was done using the recordings by transcribing them and categorizing the statements using a classification scheme for the main issues: electricity consumption and energy management, flexible technologies and options for DR, and drivers and barriers towards DR. For our evaluation, we distinguished between general and sector-specific findings. 
Table 2 Selected stakeholders for the interviews

\begin{tabular}{lll}
\hline Scope & Stakeholder & Organization of interviewee \\
\hline Superordinate & Aggregator & EnerNOC \\
& Energy services & Next Kraftwerke (virtual power plant operator) \\
& Beegy (energy service provider) \\
& EnBW (energy provider south Germany) \\
& Tübingen SW (local communal energy provider) \\
& EnQS (consulting, public services on energy management) \\
& Transnet BW (TSO south-west Germany) \\
& Regulator & Sicotronic (load management solutions for hotels/ restaurants) \\
& BNetzA (Bundesnetzagentur, German regulator for electricity \\
Retail trade & grids/ networks) \\
& HDE (German association of retail trade enterprises) \\
Hotels/restaurants & EHI (research institute for retail trade) \\
& Adelphi (project management; managing energy section for the \\
& German hotel and gastronomy association DEHOGA) \\
& PWC (consulting enterprise with own energy management section) \\
& Vollack (project management and planning office for builders)
\end{tabular}

\section{Results}

Identifying flexible technologies and promising subsectors in the service sector based on survey data

We used two criteria to select our subsectors of interest for DR: energy consumption of the sector and the availability of flexible technologies. We first introduce our selection of flexible technologies based on prior research. Then, we analyze the balances for electricity consumption in the different subsectors to identify the most consuming ones and those with large shares of flexible demand.

\section{Identifying potentially flexible technologies within the subsectors}

Regarding the technical potential, we consider especially appliances, which technically allow a certain flexibility of demand within the chosen subsectors. Table 3 shows our set of flexible technologies, relying mainly on compilations of flexible technologies of Klobasa (2007), VDE (2012), and Gils (2014). We assessed those and only regarded electric appliances with a significant share in total load or consumption and whose load can be flexibly adjusted to some degree without influencing the core of the enterprises' business. Thus,
Table 3 Flexible appliances in the service sector

\begin{tabular}{|c|c|c|}
\hline Type of appliance & Flexible appliance & $\begin{array}{l}\text { Containing category from } \\
\text { energy balances for } \\
\text { appliances (cp. Table 4) }\end{array}$ \\
\hline \multirow[t]{3}{*}{ Cooling } & Cold storage & Process cold \\
\hline & Retail cooling & Process cold \\
\hline & Hotel/restaurant cooling & Process cold \\
\hline \multirow[t]{2}{*}{ Air conditioning $(\mathrm{AC}) /$ ventilation } & Ventilation & Mechanical power \\
\hline & Air conditioner & Air conditioning \\
\hline Warm water & Electric water heating & Hot water \\
\hline \multirow[t]{2}{*}{ Room heating } & Storage heater & Space heating \\
\hline & Heat pump/recirculation pump & Space heating \\
\hline
\end{tabular}


we finally arrived at a set of technologies describing essentially appliances of cooling, heating, and air conditioning (Table 3).

\section{Identifying promising subsectors}

To evaluate the most appropriate subsectors for DR, we then analyze the energy consumption of each subsector (Table 4) using the data assembled in the survey (Schlomann et al. 2015). The numbers on the electricity consumption of 2013 show that the subsectors officelike enterprises, retail trade and hotels, restaurants, and homes consume by far the most electricity. Considering consumed electrical energy as an indicator, this suggests a high theoretical DR potential for those sectors. Together, they account for more than 50\% of total electric energy consumption of the tertiary sector $(70.5 \mathrm{TWh} / \mathrm{a}$, about $14 \%$ of Germany's total electricity consumption), while the rest is split up into smaller shares over a larger number of structurally different subsectors. This means in effect, that covering those three subsectors concurrently involves the largest parts of the sector. Having a more homogenous group of enterprises, sector-typical standards can be established more easily, compared to approaching more compartmentalized sectors.

The last column of Table 4 "sum of relevant shares" is the sum of the consumption of the flexible appliances (cp. Table 3 and highlighted in italics), indicating the available theoretical flexibility potential. This value needs to be revised downwards, as not the whole consumption of an appliance is technically flexible. However, the numbers allow comparisons and show that regarding flexible technologies; our selected sectors still point out the largest potential compared to other subsectors. The findings are in line with Klobasa (2007): He argues that the most interesting appliances allowing DR are found predominantly in those sectors, viz. cooling, heating, and air conditioning due to their function as energy storage.

The next sections focus on practicability of DR in our selected sectors, taking the stakeholder interviews into account.

Table 4 Electricity consumption in tertiary sectors (including service) 2013 (Schlomann et al. 2015)

\begin{tabular}{|c|c|c|c|c|c|c|c|c|c|c|}
\hline $\begin{array}{l}2013 \\
\text { Electricity consumption } \\
\text { (TWh/a) }\end{array}$ & Lighting & $\begin{array}{l}\text { Mech. } \\
\text { power }\end{array}$ & $\begin{array}{l}\text { Hot } \\
\text { water }\end{array}$ & $\begin{array}{l}\text { Other } \\
\text { process } \\
\text { heat }\end{array}$ & $\begin{array}{l}\text { Process } \\
\text { cold }\end{array}$ & $\mathrm{AC}$ & ICT & $\begin{array}{l}\text { Space } \\
\text { heating }\end{array}$ & Total & $\begin{array}{l}\text { Sum of } \\
\text { relevant } \\
\text { shares }\end{array}$ \\
\hline Construction industry & 1.8 & 0.7 & 0.5 & 0.1 & 0.0 & 0.1 & 0.3 & 0.3 & 3.8 & 0.9 \\
\hline Office-like enterprises & 13.3 & 1.3 & 0.9 & 0.4 & 0.7 & 0.9 & 10.9 & 1.1 & 29.5 & 3.6 \\
\hline $\begin{array}{l}\text { Small manufacturing } \\
\text { enterprises }\end{array}$ & 1.5 & 1.6 & 0.2 & 0.0 & 0.0 & 0.0 & 0.4 & 0.2 & 3.9 & 0.4 \\
\hline Retail trade & 11.0 & 2.1 & 0.7 & 0.6 & 4.2 & 0.5 & 1.9 & 1.4 & 22.5 & 6.8 \\
\hline Hospitals & 1.2 & 1.7 & 0.3 & 1.7 & 0.1 & 0.3 & 0.6 & 0.1 & 6.1 & 0.8 \\
\hline Schools & 2.9 & 0.1 & 0.1 & 0.1 & 0.0 & 0.0 & 0.4 & 0.1 & 3.9 & 0.3 \\
\hline Baths & 0.2 & 1.1 & 0.0 & 0.0 & 0.0 & 0.0 & 0.0 & 0.0 & 1.4 & 0.0 \\
\hline Hotels, restaurants, homes & 5.3 & 4.8 & 1.3 & 2.1 & 2.5 & 0.2 & 1.0 & 1.4 & 18.5 & 5.4 \\
\hline $\begin{array}{l}\text { Foodstuff (bakers, butchers, } \\
\text { other) }\end{array}$ & 0.2 & 0.1 & 0.0 & 0.4 & 0.1 & 0.0 & 0.0 & 0.0 & 0.9 & 0.3 \\
\hline Laundries & 0.1 & 0.0 & 0.0 & 0.2 & 0.0 & 0.0 & 0.0 & 0.0 & 0.3 & 0.0 \\
\hline Agriculture & 1.1 & 1.8 & 0.5 & 0.0 & 0.1 & 0.4 & 0.2 & 0.2 & 4.3 & 1.3 \\
\hline Horticulture & 0.2 & 0.0 & 0.1 & 0.0 & 0.0 & 0.0 & 0.0 & 0.0 & 0.4 & 0.1 \\
\hline Airports & 0.5 & 0.4 & 0.1 & 0.1 & 0.0 & 0.1 & 0.1 & 0.1 & 1.3 & 0.3 \\
\hline Textile, clothing, leather & 0.6 & 0.1 & 0.0 & 0.0 & 0.0 & 0.0 & 0.2 & 0.2 & 1.1 & 0.2 \\
\hline Remaining groups* & 1.1 & 7.9 & 0.1 & 0.4 & 2.9 & 0.0 & 4.1 & 0.2 & 16.8 & 3.3 \\
\hline Other & 5.8 & 8.6 & 0.2 & 0.2 & 0.1 & 0.1 & 1.0 & 0.0 & 15.9 & 0.4 \\
\hline Total & 46.7 & 32.5 & 5.0 & 6.2 & 11.0 & 2.7 & 21.1 & 5.4 & 130.6 & 24.1 \\
\hline
\end{tabular}

*Not covered by the questionnaire

Deviations in the totals may occur due to rounding errors 
Evaluating framework conditions, barriers and options to tap the DR potential in the service sector

The basis of our evaluation, which considers practical issues when implementing DR measures are the interviews conducted with stakeholders for DR in the service sector. If appropriate, findings from literature are added. We focus on the specific issues of each subsector after giving an overview of general findings for all considered subsectors.

\section{Office-like enterprises}

Our interviewees stated that for office-like businesses, DR is a non-issue so far. However, they also see potential for DR, e.g., in AC and ventilation or measures like using the building as energy storage. In that case, the building would for example be cooled down already overnight in the summer time if overcapacities of energy are available; the energy is thereby stored in concrete ceilings. Habits of staff might interfere with DR measures, e.g., if AC is used for DR, people opening windows disturb the order of the system and leads to a restricted predictability of the loads. The interviewees especially pointed out that measures must not impair the comfort of the staff, because the quality of their work could suffer. In a way, they see the same problem as the manufacturing industry here, fearing a loss of product quality caused by DR measures. In line with their former experiences from energy efficiency issues, they still expect that low-hanging fruits for DR can be reaped without jeopardizing the acceptance of the staff. Knowledge and required technology seems to be easily accessible. But also awareness and the support of experts for the implementation of measures will be needed to assure the necessary trust and acceptance. In larger, modern office buildings, control technology is already available but often untapped for the purpose of optimizing energy consumption (efficiency as well as DR). In other cases, upgrades and retrofits to enable DR are considered as a possibility to implement DR measures, but the required investments make profitability a relevant barrier. However, there are fewer intrinsic incentives for DR than for energy efficiency measures. Thus, enterprises need to be approached by aggregators or suppliers with offers valuing their demand flexibility. The interviewees did not expect that the business owners in the offices would agree to hand over the control of appliances to somewhere outside the building. Thus, a starting point is seen in individual contracts with energy suppliers so that the dialogue and interaction are given and mutual appreciation can be preserved.

Offices need to be seen as a special case in comparison to our other selected subsectors, because it is no subsector in the strict sense. That is why there are no associations or other structures that organize those businesses to spread knowledge or to raise such like issues. Instead, flagship projects for DR might function to raise awareness and prove feasibility.

\section{Retail trade}

DR potential in the trade sector as a whole lies in ventilation and AC. Regarding food retail, a large potential can be attributed to cooling and cold storage appliances, where also a large share in electricity consumption is caused. Additionally, unique technologies for specific kinds of markets were mentioned, such as baking machines for baked goods in self-service markets or TVs in hifi stores. In addition, the use of CHP and emergency generators was suggested as possible appliances for DR. Since in the trade sector (esp. food), electricity costs are an important issue and the market potential of DR has been recognized; the usage of cooling and AC for DR is being evaluated among representatives of the subsector. Like this, DR options seem to be most actively taken into consideration within the trade sector compared to the other subsectors. Nevertheless, they feel overlooked and discriminated against by regulatory conditions, especially compared to the industry sector. Until the revision of the AbLaV, taking advantage of that regulation was apparently meant for energy-intense industry enterprises. Yet, pooling of loads is still difficult.

In practice, using cooling appliances for DR in retail stores is difficult, because it has to involve customer behavior: If appliances are switched off for DR purposes, a constant temperature still has to be guaranteed to keep a constant cooling chain for the foodstuff, i.e., the refrigerator needs to stay closed, because warm air is let into the cooling devices if customers open them. Taking out food also means to take away the medium for stored energy (cold, in this case), which additionally decreases the profit margin of the frozen food.

Concerning AC, some companies try to combine and control flexible loads of several stores of a corporate chain. Generally, corporate chains are seen as favorable pioneers: only the headquarter needs to be convinced, 
communication is easier as the single enterprises already have connected structures, purchases are centralized, and measures could be rolled out for larger number of enterprises in one go. Above that, larger chains or enterprises often have regular phases of refurbishment or renovation when such like measures could be implemented and installation of control systems or change of appliances can be arranged. Monitoring systems and decentralized control systems are common, esp. in larger stores. However, there are yet few centralized automatic control systems, since data security is an issue there. Regarding the existing competition between the different corporate chains, pooling of loads over branches of one chain is regarded to be much easier than if rival companies are involved. Therefore, there might be inhibition thresholds towards other third parties as aggregators. Considering that most enterprises of the sector are branch stores of larger chains, the competition could be used to raise pressure to participate, e.g., if a flagship project has been successful and raised the interest in DR. Yet, our interviewees assume, that the courage to run the risk is possibly missing.

\section{Hotels, restaurants, and homes}

Enterprises from this sector usually have AC, ventilation, and cooling devices (refrigerators and freezers) available, which can be used for DR. Above all, kitchens have high loads and electricity consumption, especially those including heating processes. Hence, enterprises with large kitchens usually have special contracts with their energy supplier. If they want to save costs by keeping that load under a defined level, they are equipped with an intelligent load management system controlling their kitchen devices. According to an example given by our interviewed technology supplier, large kitchens can have approximately $700 \mathrm{~kW}$ of connected load which causes peaks of about $500 \mathrm{~kW}$. Using controlling systems, appliances can be rescheduled to reduce peak load to $300 \mathrm{~kW}$. For some appliances, only heating processes are delayed, while the appliance itself keeps running. An industrial standard (DIN 18875) has been developed, so theoretically all appliances with heat output could be taken into account. However, load shedding (in the sense of switching off appliances for a while) is not appropriate for cooking devices in kitchens, because when guests arrive and meals have to be prepared; the devices have to be ready on demand. Yet, devices like plate warmers or heating cabinets can be switched off for time intervals. Depending on the complexity and number of appliances, costs for those intelligent load management installations amount to a four- to five-digit euro range. Yet, according to our interviewed technology supplier, they usually pay off after a few years.

For some appliances, the flexible controllability might bear additional benefits, e.g., if ventilation can be controlled and downregulated overnight, noise is reduced for guests in their hotel rooms with gains in comfort. An automated regulation of AC can be used for DR without losses in comfort when it is regulated within the target range of temperatures. The control of the appliance under these conditions is rather acceptable from outside of the enterprise.

The following Table 5 summarizes the key findings for each of our considered subsectors:

\section{General findings applying for all subsectors}

All interviewed stakeholders agreed with the general relevance of DR for the efficiency of the future energy system and its gains for sustainability. In respect thereof, they did not perceive conflicts between pursuing concepts of energy efficiency vs. DR, but pointed out the advantages: Regarding system level, DR with the aim that demand follows generation is seen as a way of contributing to energy efficiency. On the level of the enterprise, knowledge acquired about energy issues by dealing with energy efficiency measures and possibly installed technologies to control the demand of appliances can promote the implementation of DR. With the necessary expertise, upgrading infrastructure to be DRready, could be done with a little more effort in the course of refurbishments or if appliances are changed anyway. Such measures can comprise multiple benefits: e.g., insulating the building means energy savings and can also go hand in hand with higher comfort and larger potentials for DR as the building keeps temperatures better and can therefore function as energy storage. On the level of single appliances, DR can interfere with energy efficiency issues, especially if a flexible use means an appliance is operated inefficiently. Efficiency on the energy system level, however, does not necessarily mean to reduce consumption to a lower level, especially if (surplus) energy is used when it is available.

The issue of comfort is mentioned often by the stakeholders for subsectors but deemed overrated by other experts. In this regard, our interviewee for technology 
Table 5 Summary of interview results

\begin{tabular}{|c|c|c|c|}
\hline & Offices & Retail trade & Hotels/restaurants \\
\hline $\begin{array}{l}\text { Most } \\
\text { appropriate } \\
\text { appliances }\end{array}$ & $\mathrm{AC}$, ventilation & $\begin{array}{l}\text { Ventilation, AC, cooling/ cold } \\
\text { storage }\end{array}$ & $\begin{array}{l}\text { AC, ventilation, refrigerators, } \\
\text { kitchen devices }\end{array}$ \\
\hline Drivers & $\begin{array}{l}\text { "Low-hanging fruits" - untapped potentials, } \\
\text { appliances of interest not part of core business }\end{array}$ & $\begin{array}{l}\text { Cooling and AC for DR already } \\
\text { evaluated } \\
\text { Competition between corporate } \\
\text { chains (competitive advantage) }\end{array}$ & $\begin{array}{l}\text { High loads (esp. in kitchen) } \\
\text { Load management common for } \\
\text { kitchen devices in large } \\
\text { companies } \\
\text { Possible gains in comfort due to } \\
\text { controlling software }\end{array}$ \\
\hline Barriers & $\begin{array}{l}\text { Habits/ routines of staff } \\
\text { Fear of loss in quality } \\
\text { No handing over of control }\end{array}$ & $\begin{array}{l}\text { Feeling of discrimination against } \\
\text { industry } \\
\text { Customer might impede DR } \\
\text { Competition between corporate } \\
\text { chains (pooling) }\end{array}$ & $\begin{array}{l}\text { DR may not impose } \\
\text { routines/comfort of customers }\end{array}$ \\
\hline Starting points & $\begin{array}{l}\text { Individual contracts with providers } \\
\text { Flagship projects } \\
\text { Modern buildings already dispose of control } \\
\text { software for facility management }\end{array}$ & $\begin{array}{l}\text { Regular phases of refurbishment } \\
\text { Chains/ associations facilitate } \\
\text { roll-out }\end{array}$ & $\begin{array}{l}\text { Load controlling systems in } \\
\text { kitchens }\end{array}$ \\
\hline
\end{tabular}

supply simply poses the question: "How long would it take you to recognise that the $\mathrm{AC}$ is not working properly?" Regarding barriers, preservation of quality of work and goods, financial risks of DR, data security, safety regulations and missing knowledge about DR were also mentioned.

The interviewees assume that knowledge about energy issues and the availability of control technologies for applications will increase within the next few years, which simultaneously advances options for DR: control systems for energy consumption are considered to be state of the art in modern facility management and will diffuse with newly constructed buildings. Additionally, by article 8 of the EED (energy efficiency directive), large enterprises have been obliged (and small and medium sized enterprises encouraged) to conduct mandatory energy audits over a 4-year cycle, starting 5th December 2015. Alternatively, a certified EMS can be approved. These actions are meant to increase the involvement of enterprises regarding energy efficiency issues and will support the generation of knowledge and the introduction of management systems.

According to the stakeholders, the enterprises of the subsectors selected for our analysis usually have more experience with energy efficiency issues than with DR. The companies from the service sector usually do not meet the regulatory requirements yet, nor do service providers or energy suppliers approach the service sector with options to participate in DR. However, most companies know about their typically largest electricity consumers. Opportunities for DR are predominantly seen in larger enterprises, as only in those the load level and the electricity costs are high enough to raise awareness of this topic. Moreover, some companies already have energy management systems (EMS) available. Those companies might also have energy managers or personal capacities to organize direct participation at the spot market, but only if adequate profits can be expected.

To subsume, changes in regulations, energy management and technological developments can become dooropeners for DR. At the moment, the existing markets for DR are still inaccessible or not profitable. To tap the existing DR potential, offers and contracts need to be established to raise interest in these issues.

Starting points to tap the DR potential in the service sector and policy recommendations

Having evaluated promising subsectors and technologies as well as specific conditions and status quos for the subsectors, we derive starting points to tap the open potentials for DR as well as first policy recommendations.

Regarding regulatory conditions, there are, e.g., the access charges (StromNEV), which interfere with the concept of DR. The idea of that regulation reflects that energy generation up to today is characterized by constant loads and deviations need to be compensated by 
balancing loads. Energy sources of the future are more volatile, which makes the ideal of constant consumption obsolete. The access charges should change according to the changed conditions and that regulation should be redesigned: offering schedulable demand flexibility should be rewarded instead of permanence. A rising share of renewable energy generation might increase the value of DR and induce more attractive prices and easy accessible markets for flexible loads.

To improve the accessibility of markets in turn, lowering minimum bids for participation has currently been done, which should go hand in hand with an easier prequalification of appliances. Involving aggregators to facilitate, offering DR also for smaller providers is still complicated and standardized processes and contracting are lacking. Possible improvements are under discussion and are needed to remove the barrier of unfavorable market conditions. Concerning market design, several interviewees suggested that the AbLaV could be integrated into the operating reserve market. The AbLaV and the operating reserve market seem to have the same purpose and are working in a similar way, while the $\mathrm{AbLaV}$ seemed to be semi-opened in the past, however, due to requirements, it is only accessible for industrial enterprises. A contribution of electricity consumers to DR can also indirectly be fostered by electricity providers by including more flexible tariff models. A real-time pricing tariff can function as a way to participate in DR on a lower level, without the barrier of minimum bids. Time-of-use tariffs can be a lighter option where flexibility can be pre-scheduled. This option would not necessarily require an external control of appliances, and the tariff could be chosen with regard to the processes and consumption patterns of the enterprise.

In general, all market offers to trade flexibility have to meet the regulations. This means that regulatory improvements have to be made before new concepts can be successfully established. Different ways of marketing flexibility besides trading loads at the balancing and spot markets could be developed, e.g., networkconductive services within agreements with the network operator. Thus, new market participants might come into play.

Regarding the current situation, existing tools and regulations could be utilized to support the use of untapped DR potentials. Many enterprises dispose of management software or even control devices, which could be used or upgraded for DR purposes. Hence, getting started with DR might take lower investments than expected. This especially pertains to larger enterprises with relatively large potentials. The recast of EPBD (Energy Performance of Buildings Directive) on 30 November 2016 of the European Commission (European Commission 2016) might be a necessary and logical step to integrate the readiness of buildings for DR into a regulatory framework. It introduces the "smart indicator" rating "the readiness of the building to adapt its operation to the needs of the occupant and of the grid and to improve its performance" and reinforces the use of electronic building monitoring, automation, and control. As we learned from our interviews, modern control technologies for facilities are becoming increasingly common and are standard in newly constructed buildings. Even now, existing technologies are barely used for considering DR potentials, partly because enterprises see no relevance or have no experience. Field studies and practical trials could raise awareness and inspire confidence in the functioning of DR concepts. Trials like that can reduce concerns towards DR measures and their success will raise interest for further participants to get started. The service sector is usually seen as less sensitive for data security issues concerning energy consumption data than the industrial sector. This might facilitate to spread the word and publish exemplary data or evaluations from early adopters of DR measures. Information can also be delivered within the scope of energy audits, which are mandatory now for large enterprises (EED Article 8, resp. revision of EDL$\mathrm{G}$ in Germany) anyway. The consultation of DR potentials could easily be integrated and does not need to be restricted to energy saving potentials when data on energy consumption is already gathered and evaluated.

\section{Discussion and conclusions}

In this article, we focused on promising subsectors of the service sector and their DR potentials. We based our selection of subsectors on quantitative data, while the considerations of starting points to tap the DR potential and opportunities for DR measures were approached by qualitative interview data. Integration of service sector's DR potential is not necessary or financially attractive at the moment, because backup power plants and DR offered by the energy intensive industries maintain the grid stability. Accordingly, our considerations are forward-looking under the premise that the stated aims 
of increasing shares of renewable energies will cause changes in the energy system and flexible demands will be of greater interest. First steps in regulatory changes have already been taken which will facilitate to touch the open potentials. Nevertheless, numbers are still hard to assess because prices for flexible loads under future circumstances cannot be foreseen yet. To learn more about quantified practical potentials, price sensitivity and willingness, data on a large number of enterprises has to be ascertained.

We concluded that the most promising potentials for the subsectors of trade, restaurants, hotels and homes, and office-like buildings. Concerning technologies, cooling appliances, air conditioning, ventilation, electrical hot water generation, and room heating seem most suitable for DR measures. All of them pertain to crosssectoral technologies in the service sector and are especially common in our selected sectors. In our interviews with stakeholders, we found that all of our selected subsectors see options for DR to some degree and have taken steps, which conduce to tap that potential. Usually, appliances with flexibility potential or technical preconditions are already available resp. control software for facility management becomes more and more common with the modernization of buildings. Hence, it seems that in the future, less financial effort is needed for technical equipment to realize DR. Regarding the fulfillment of the requirements and the profitability of measures, larger enterprises are usually better qualified than smaller ones. In any case, experiences with energy efficiency issues are seen as useful to get into DR and to find measures to start with. On the other hand, acceptance issues have to be addressed. Barriers like lack of awareness, having no persons in charge, financial issues, worries about quality, loss of work or products, and regulatory circumstances were mentioned. Furthermore, enterprises are reluctant to hand over the control over appliances to external operators.

Results regarding regulatory conditions are countryspecific and therefore need to be considered individually for each country. Our results on sector-specific issues and concerns related to special applications can largely be internationally transferred, because they are specific for applications or sectors, but not country-specific. Thus, they can be used for practical considerations of DR potentials.

Our next steps will include a quantitative survey in our selected sectors about available flexible appliances, experiences with DR, attitudes and organizational circumstances influencing DR opportunities, allowing estimations of technical and practical potentials of DR.

Acknowledgements We thank the German Federal Ministry for Economic Affairs and Energy (BMWi) for the support of the underlying project "Flexible Nachfrage als wichtiger Beitrag zur Energiewende und Baustein in der Energiesystemanalyse" (EnSys-FlexA) and the many stakeholders for their time and input, sharing their experiences and ideas with us.

\section{Compliance with ethical standards}

Conflict of interest The authors declare that they have no conflict of interest.

Open Access This article is distributed under the terms of the Creative Commons Attribution 4.0 International License (http:// creativecommons.org/licenses/by/4.0/), which permits unrestricted use, distribution, and reproduction in any medium, provided you give appropriate credit to the original author(s) and the source, provide a link to the Creative Commons license, and indicate if changes were made.

\section{References}

AbLaV (2016). Verordnung über Vereinbarungen zu abschaltbaren Lasten (Verordnung zu abschaltbaren Lasten - AbLaV). BGBl. I S. 1984.

AGEB (Arbeitsgemeinschaft Energiebilanzen e.V.) (2014). Energiebilanzen der Bundesrepublik Deutschland 19902012 und Auswertungstabellen 1990-2013. Stand September 2014. DIW Berlin, EEFA, Köln. http://www.agenergiebilanzen.de

AGEB (Arbeitsgemeinschaft Energiebilanzen e.V.) (2015). Energy balance 2013. http://www.ag-energiebilanzen.de/71-Energy-Balance-2000-to-2013.html. Accessed 4/6/2016.

Bayer, B. (2014). Demand Response - sind die USA ein Vorbild für Deutschland? Eine Analyse der Integration von Demand Response in die US-amerikanischen Kapazitäts- und Regelleistungsmärkte. IASS Working Paper, Juni 2014. https://doi.org/10.2312/iass.2014.010

BNetzA (2016). Vorschlag der Bundesnetzagentur zum Aggregator-Modell. Date of release: 22.02.2016. Available at: https://www.bundesnetzagentur.de/SharedDocs/ Downloads/DE/Sachgebiete/Energie/Unternehmen Institutionen/VortraegeVeranstaltungen/Aggregator_Modell_606.pdf Retrieved 03.03.2017.

California Public Utilities Commission. Information on DR programmes and research. http://www.cpuc.ca.gov/General. aspx?id=5924 retrieved 27.07.2017.

Cowart, R et al. (2003). Dimensions of demand response: capturing customer based resources in New England's power systems and markets - report and recommendations of the New 
England demand response initiative. The regulatory assistance project.

Dena (Deutsche Energie-Agentur GmbH) (2010). Integration erneuerbarer Energien in die deutsche Stromversorgung im Zeitraum 2015-2020 mit Ausblick auf 2025. denaNetzstudie II. Berlin.

Deutscher Bundestag (2010). Energiekonzept für eine umweltschonende, zuverlässige und bezahlbare Energieversorgung und 10-Punkte-Sofortprogramm Monitoring und Zwischenbericht der Bundesregierung. Berlin (Drucksache 17/3049).

Element Energy Limited, De Montfort University (2012). Demand side response in the non-domestic sector: final report for Ofgem. Cambridge.

Eßer, A., Haendel, M., Klobasa, M. (2016). Möglichkeiten für grenzüberschreitenden Handel mit lastseitigen Flexibilitäten in Deutschland, Frankreich, Schweiz und Österreich im Rahmen des Pilotprojekts Demand Side Management Baden-Württemberg. A study of the Fraunhofer Institute for Systems and Innovation Research ISI on behalf of the German Energy Agency (dena). Available: http://publica. fraunhofer.de/dokumente/N-445784.html. Accessed 8/28/18.

European Commission (2016). Proposal for a Directive of the European Parliament and of the Council amending Directive 2010/31/EU on the energy performance of buildings. Brussels, 30.11.2016. Available at: http://ec.europa. eu/energy/sites/ener/files/documents/1_en_act_part1_v10. pdf retrieved: 06.03.17.

Finn, P., \& Fitzpatrick, C. (2014). Demand side management of industrial electricity consumption. Promoting the use of renewable energy through real-time pricing. Applied Energy, 113, 11-21. https://doi.org/10.1016/j.apenergy.2013.07.003.

Focken, U., Bümmerstede, J., Klobasa, M. (2011). Kurz- bis Mittelfristig realisierbare Marktpotenziale für die Anwendung von Demand Response im gewerblichen Sektor. Edited by energy meteo systems GmbH, Fraunhofer-Institut für System und Innovationsforschung (Fh ISI). Oldenburg, Karlsruhe. Available: http://publica. fraunhofer.de/dokumente/N-207037.html.

Gils, H. (2014). Assessment of the theoretical demand response potential in Europe. Energy, 67, 1-18. https://doi. org/10.1016/j.energy.2014.02.019.

Goldman, C., Hopper, N., Bharvirkar, R., Neeman, B., Cappers, P. (2007). Estimating Demand Response Market Potential among Large Commercial and Industrial Customers. A Scoping Study. The work described in this report was funded by the Permitting, Siting and Analysis Division of the Office of Electricity Delivery and Energy Reliability of the U.S. Department of Energy under Contract No. DE-AC0205CH11231. Edited by SciTech Connect. Ernest Orlando Lawrence Berkeley National The Laboratory. Berkley, CA.

Grein, A., \& Pehnt, M. (2011). Load management for refrigeration systems: potentials and barriers. Energy Policy., 39, 55985608. https://doi.org/10.1016/j.enpol.2011.04.040.

Grein, A., Pehnt, M., Duscha, M., Kellerbauer, H. (2009). Nutzung von thermischen Speichern als Energiespeicher. Edited by Bundesministerium für Umwelt, Naturschutz und Reaktorsicherheit (BMU).

IEA (2016). Roles and potentials of flexible consumers and prosumers. Demand flexibility in households and buildings. IEA DSM task 17. IEA DSM Enery efficiency. Available:
http://www.ieadsm.org/wp/files/IEA-DSM-Task-17Subtask-10-role-and-potentials-2016-09-29.pdf

Jahn, A., Gottstein, M. (2013). Nachfragesteuerung im deutschen Stromsystem. die unerschlossene Ressource für die Versorgungssicherheit. Edited by The Regulatory Assitance Project (RAP). Berlin.

Kiliccote, S., Piette, M., Mathieu, J., Parrish, K. (2010). Findings from seven years of field performance data for automated demand response in commercial buildings. Lawrence Berkeley National Laboratory. http://escholarship. org/uc/item/7m408394

Klobasa, M. (2007): Dynamische Simulation eines Lastmanagements und Integration von Windenergie in ein Elektrizitätsnetz auf Landesebene unter regelungstechnischen und Kostengesichtspunkten. doctoral thesis. ETH Zürich, Zürich. Available: http://publica. fraunhofer.de/dokumente/N-68615.html.

Klobasa, M., Angerer, G., Schleich, J., Buber, T., Gruber, A., Marie, H., von Roon, S. (2013). Lastmanagement als Beitrag zur Deckung des Spitzenlastbedarfs in Süddeutschland. Endbericht einer Studie von Fraunhofer ISI und der Forschungsgesellschaft für Energiewirtschaft. Agora Energiewende. Berlin, checked on 21.03.2016. Accessed 8/28/18.

Olsthoorn, M., Schleich, J., \& Klobasa, M. (2015). Barriers to electricity load shift in companies. A survey-based exploration of the end-user perspective. Energy Policy, 76, 32-42. https://doi.org/10.1016/j.enpol.2014.11.015.

Palensky, P., Dietrich, D. (2011). Demand Side Management: Demand Response, Intelligent Energy Systems, and Smart Load. IEEE Transactions on Industrial Informatics, VOL. 7, NO. 3, AUGUST 2011. 381-388.

Regelleistung.net (2016). List of prequalified providers of operating reserve. Status of 14.12.16. Available at: https://www. regelleistung.net/ext/download/anbieterliste. Retrieved: 12.01.17.

Regelleistung.net (2017). Sheddable loads - number of framework contracts. Available at: https://www.regelleistung. net/ext/static/abla. Retrieved: 12.01.17.

Rudolph, M., Wagner, U. (1997). Begriffe der Versorgungswirtschaft Teil D Energie Heft 1: Energiewirtschaftliche Grundbegriffe. VWEW Verlag. Frankfurt a. M.

Schlomann, B., Wohlfarth, K., Kleeberger, H., Hardi, L., Geiger, B., Pich, A., Gruber, E., Gerspacher, A., Holländer, E., Roser, A. (2015). Energy consumption of the tertiary sector (trade, commerce and services) in Germany for the years 2011 to 2013: Final Report to the Federal Ministry for Economic Affairs and Energy (BMWi). Karlsruhe, Munich, Nuremberg, February 2015. Available: http://publica. fraunhofer.de/documents/N-285560.html. Accessed 8/28/18.

SEDC (2015). Mapping Demand Response in Europe 2015. Available at: http://www.smartenergiedemand.eu/?p=6533. Retrieved: 06.09.2016.

Stadler, I. (2005). Nichtelektrische Speicher für Elektrizitätsversorgungssysteme mit hohem Anteil erneuerbarer Energien. In Habilitation. Kassel. Elektrotechnik: Universität Kassel.

StromNEV (2005). Verordnung über die Entgelte für den Zugang zu Elektrizitätsversorgungsnetzen (Stromnetzentgeltverordnung StromNEV). BGB1. I S. 2225, zuletzt geändert am 22. Dezember 2016 BGB1. I S. 3106. 
VDE Verband der Elektrotechnik Elektronik Informationstechnik e.V. (Hrsg., 2012). Ein notwendiger Baustein: Demand Side Integration, Lastverschiebungspotenziale in Deutschland. ETG Task Force Demand Side Management. Juni 2012, Frankfurt a. M.

von Roon, S., \& Gobmaier, T. (2010). Demand Response in der Industrie. Status und Potenziale in Deutschland. München: Forschungsstelle für Energiewirtschaft e.V.

Weißbach, T. (2015). DSM - Erfahrungen und Perspektiven aus Sicht eines Übertragungsnetzbetreibers, Transnet BW,
Vortrag im Rahmen des Projekttreffens Demand Side Management in Baden Württmeberg, Stuttgart, 14.12.2015.

Western University of Ontario (2017). FM nods to campus for conservation successes. http://news.westernu.ca/2015/06/fmnods-to-campus-for-conservation-successes/ retrieved: 27.07.2017 Global Adjustment: http://www.uwo. $\mathrm{ca} / \mathrm{fm} /$ initiatives/global_adjustment.html\#whatis retrieved: 27.07.2017. 